\title{
Malondialdehyde (MDA) Ovary and Estradiol Blood Serum Levels of Premenopause White Rat (Rattus norvegicus) after Turmeric Powder (Curcuma longa L.) Treatment
}

\author{
Teguh Suprihatin ${ }^{1,2}$, Sri Widyarti ${ }^{3}$, Muhaimin Rifa'i ${ }^{3}$, Sri Rahayu ${ }^{3 *}$ \\ ${ }^{1}$ Doctoral Student of Biology, Department of Biology, Faculty of Mathematics and Natural Sciences, Brawijaya \\ University, Malang 65145, Indonesia \\ ${ }^{2}$ Department of Biology, Faculty of Mathematics and Natural Sciences, Diponegoro University, Semarang \\ 50275, Indonesia \\ ${ }^{3}$ Department of Biology, Faculty of Mathematics and Natural Sciences, Brawijaya University, Malang 65145, \\ Indonesia
}

Article history:

Submission June 2019

Revised July 2019

Accepted September 2019

*Corresponding author:

E-mail:

srahayu@ub.ac.id

\begin{abstract}
Premenopause is a physiological condition in a female individual that has entered the aging period, a condition usually characterized by elevated MDA levels and decreased estrogen levels. The objective of this study was to determine the level of ovarian MDA and estradiol serum levels of premenopausal white rat blood after oral turmeric powder treatment. The animals used were 30 female Wistar strains white rat, age 12 months with an average body weight 200-250 g. The animals were divided into 6 groups, namely the negative control group (P0) with $4 \mathrm{ml} /$ day distilled water treatment; positive control group (P1), this group was treated with pure curcumin powder $6.75 \mathrm{mg} / \mathrm{kg} \mathrm{BW}$; treatment group 1 (P2), group was treated with turmeric powder $100 \mathrm{mg} / \mathrm{kg} \mathrm{BW}$; treatment group 2 (P3); treatment group 3 (P4); and treatment group 4 (P5), these group were treated with turmeric powder at $200 \mathrm{mg} / \mathrm{kg}$ BW; $400 \mathrm{mg} / \mathrm{kg} \mathrm{BW}$; and $800 \mathrm{mg} / \mathrm{kg}$ BW dose respectively. Oral Treatment was administered daily for 27 days. Blood collection was performed on days 0,14 , and 28 . The ovarian collection was conducted on day 28. MDA ovarian level was measured using TBA method and blood serum estradiol level was measured using ELISA method. The results exhibited that the positive control group (P1) and the treatment group (P2-P5) showed significantly lower ovarian MDA levels compared with the negative control group (P0). The turmeric powder dose $200 \mathrm{mg} / \mathrm{kg}$ BW (P3) can increase estradiol levels by day $14(3.32 \pm 0.26 \mathrm{pg} / \mathrm{mL})$ and at day $28(4.01 \pm 0.26$ $\rho g / \mathrm{mL})$.
\end{abstract}

Keywords: Menopause, turmeric powder, curcumin, malondialdehyde, estradiol

\section{Introduction}

The age of an individual affects reproductive ability [1]. Climacteric is a transitional period from reproductive individuals to non-reproductive, which is divided into 4 stages. These stages are premenopausal, perimenopause, menopause, and postmenopausal [2]. The premenopausal stage is characterized by a gradual decline in ovarian function, estrus cycle changes, slow follicular development, and reduced estrogen hormone production [3]. Women premenopausal stage occurs at around 40 years old [4], whereas a decrease in ovarian function in mice is reported to occur at 812 months depending on the strain [5].

Turmeric powder contains curcumin that can function as an antioxidant [6]. Curcumin is an electrophilic component capable to activate $\mathrm{Nu}$ clear related factor 2 (Nrf2) which plays an important role in the transcription of second phases detoxification enzymes, such as glutathione Stransferase (GST), NAD (P) H quinone oxidore-

\section{How to cite:}

Suprihatin T, Widyarti S, Rifa'i M, Rahayu S (2019) Malondialdehyde (MDA) Ovary and Estradiol Blood Serum Levels of Premenopause White Rat (Rattus norvegicus) after Turmeric Powder (Curcuma longa L.) Treatment. Journal of Tropical Life Science 9 (3): 237 - 242. doi: 10.11594/jtls.09.03.04 
ductase 1 (NQO1) and glutamylcysteine synthetase (GCS) [7]. Phase II detoxification enzyme groups protect cells from free radicals, especially from the ROS group [8]. Reactive oxygen species (ROS) are part of free radicals derived from cellular energy metabolism and steroidogenesis processes [9].

Free radicals in the body are highly reactive (unstable) and can cause lipid peroxidation [10]. Lipid peroxidation may cause oxidative damage to long-chain unsaturated fatty acids resulting in malondialdehyde (MDA). MDA levels are often used as an index of measurement of free radical activity [11].

Turmeric powder contains curcumin and its derivatives possess biological activity as antioxidants or free radical degrader. Curcumin has an aromatic ring structure with one phenolic hydroxy group on each of its aromatic rings [12]. This phenolic hydroxy group function as a hydrogen atom donor in an unstable free radical so that it becomes more stable [9].

Turmeric powder also contains phytosterols ( $\beta$-sitosterol and stigmasterol) [13], phytosterol function as a precursor of the natural estrogen hormone (estrogenic function) because structurally and functionally, phytosterols have a structure similar to cholesterol which is a natural precursor synthesis of steroid hormones such as estrogen [14].

Turmeric powder contains curcumin which is an antioxidant and has a phenolic hydroxy group (polyphenols). It is suspected to be an electron donor to unstable free radicals [9]. The content of curcumin in turmeric powder is expected to reduce the levels of MDA which is a product of the lipid peroxidation process, where the process of lipid peroxidation is caused by the presence of free radicals which is a product of the body's normal metabolism. Turmeric powder also contains phytosterol that are thought to function as precursors of steroid hormones synthesis such as estradiol [14]. Hence its administration is orally expected to increase hormone estradiol level.

\section{Material and Methods Research design}

The research design was a complete randomized design with 6 treatments. Every method in this study was approved by Veterinary Department, Udayana University Ethics Committee (cer- tificate number: No: 204/KE-PH-Lit-1/III/2016). Each treatment was repeated 5 times. The treatment consisted of several groups, which are described as follows:

a. The negative control group (P0), a group of animals with $4 \mathrm{ml}$ distilled water

b. The positive control group (P1), a group of animals administered pure curcumin at a dose of $6.75 \mathrm{mg} / \mathrm{kg}$ body weight (BW) [15].

c. The treatment group 1 (P2), a group of animals treated with $100 \mathrm{mg} / \mathrm{kg} \mathrm{BW}$ turmeric powder [16].

d. The Treatment group 2 (P3), a group of animals which was administered with $200 \mathrm{mg} / \mathrm{kg}$ BW turmeric powder

e. The Treatment group 3 (P4), a group of animals which was administered with $400 \mathrm{mg} / \mathrm{kg}$ BW turmeric powder

f. The Treatment group 4 (P5), a group of animals treated with $800 \mathrm{mg} / \mathrm{kg}$ BW turmeric powder

\section{Animals}

The study was conducted on 30 white female rats (Rattus norvegicus) wistar strain, age 12 months, with an average weight of $200-250$ g. The animals were obtained from LPPT Gajah Mada University.

\section{Research method}

The treatment of turmeric powder is given orally on daily basis for 27 days. Blood collection was performed on days 0,14 , and 28 , followed by a procedure for measurement of blood serum estradiol levels using the enzyme-linked immunosorbent assay (ELISA) method. On the $28^{\text {th }}$ day, the animals were subject to cervical dislocation (breaking of the neck) prior to surgery. Surgery and ovarian organ collection were performed for the procedure of measuring MDA ovarian level using thiobarbituric acid (TBA) method.

\section{Determination of MDA Level by TBA Method}

Measurement of MDA levels of the ovaries used TBA reagents. Rats ovary organ was washed using saline phosphate buffer, then crushed using mortar. A potassium chloride buffer solution with ratio $1: 10$ was added afterward. The homogenate is inserted into a polypropylene tube (microtube) and centrifuged at 10,000 rpm for 10 minutes at $4^{\circ} \mathrm{C}$. The supernatant was taken at $50 \mu \mathrm{L}$ and 500 


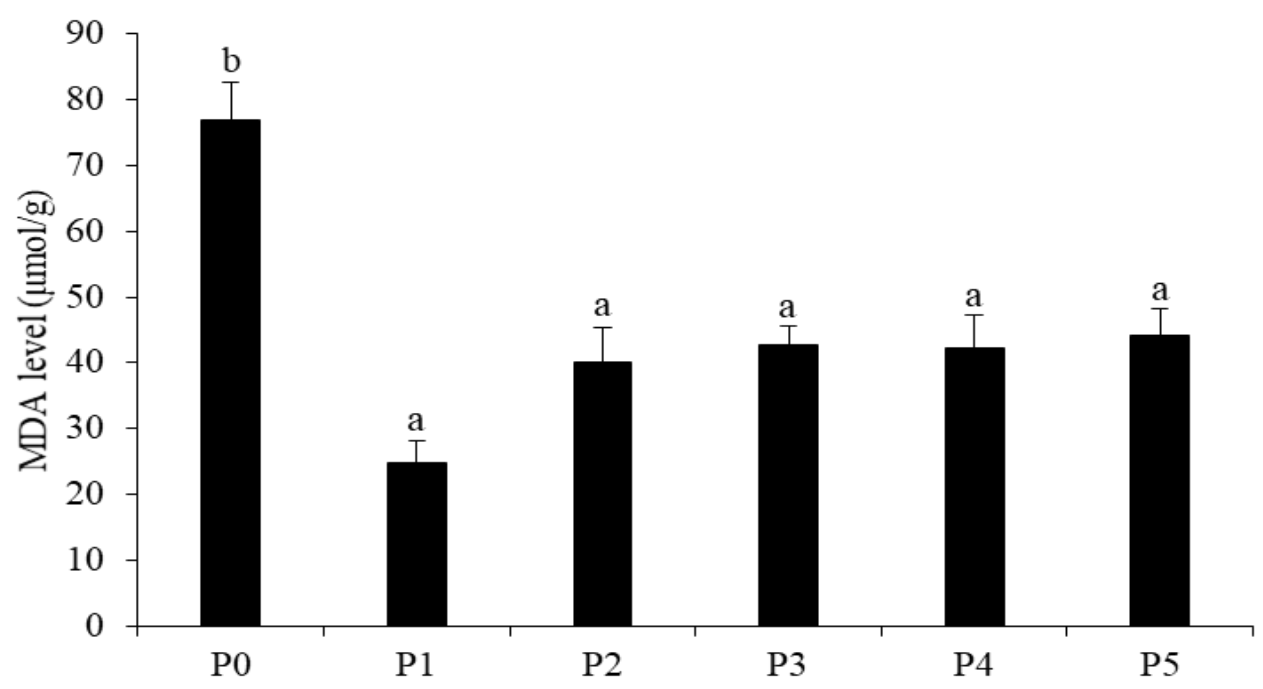

Figure 1. MDA level $(\mu \mathrm{mol} / \mathrm{g})$ of premenopausal ovarian white rats after turmeric powder treatment. P0-P5 indicate treatments. Letter indicate significant differences based on the Tukey HSD test $(\alpha=0.05)$. Error bars indicate standard error of the mean of three replicates.

$\mu \mathrm{L}$ TBA, and $250 \mu \mathrm{L}$ trichloroacetic acid (TCA) were then homogenized. The homogenate was heated using water bath at $100^{\circ} \mathrm{C}$ for 5 minutes, then centrifuged at 12,000 rpm for 5 minutes, at $25^{\circ} \mathrm{C}$. Absorbance value was determined using UV spectrophotometer at $532 \mathrm{~nm}$ wavelength [17].

\section{Determination of estradiol hormone level by ELISA method}

Blood collection is done by cutting the tail end of the animals, the blood dripping from the tail end is immediately accommodated into the ethylenediaminetetraacetic acid (EDTA) tube. After set aside for 2 hours, it was then centrifuged at 3,000 rpm for 10 minutes to obtain serum. The serum was analyzed by ELISA method using estrogen ELISA kit (Elabscience brand) to determine estradiol hormone levels.

The reagent was left at room temperature (18$25^{\circ} \mathrm{C}$ ) before use, coating was conducted into well microplate, micro-pipetting $50 \mu \mathrm{L}$ standard solution and samples were put into well microplate on different columns, $100 \mu \mathrm{L}$ estradiol enzyme conjugate for each microplate, incubation at $37^{\circ} \mathrm{C}$ for 2 hours in dark place and covered with aluminum foil, then washed with $300 \mu \mathrm{L}$ washing solution, repeated for 5 times. $100 \mu \mathrm{L}$ TBM substrate solution was added to each microplate according to the sequence. It was incubated for 20 minutes at room temperature, covered with aluminum foil. $50 \mu \mathrm{L}$ stop solution were added into each microplate gently to stop the reaction. Well microplate is inserted into ELISA spectrophotometer. It was then analyzed and observed at $450 \mathrm{~nm}$ wavelength [18].

\section{Results and Discussion}

A group of animals treated with pure curcumin powder (positive control) and a group of animals treated with turmeric powder showed significantly decreased MDA levels compared with the negative control group (aquadest). The positive control group (P1) showed the lowest decrease in MDA levels of $24.86 \pm 5.77 \mu \mathrm{mol} / \mathrm{g}$ (Figure 1).

Decreased levels of MDA after turmeric powder treatment is suspected because of the content of curcumin that serves as an antioxidant. The provision of curcumin therapy can reduce levels of MDA in the parotid gland of white rats [19]. Curcumin has antioxidant activity, a superoxide scavenger, and free radical degrader [20]. Curcumin is also thought to have a function as a species reactive oxygen cleaner and reactive oxygen species or is responsible for protecting DNA against damage caused by free radicals and protecting hepatocytes from various toxins [12].

The function of curcumin as an antioxidant and free radical degrader is thought due to curcumin structure having phenolic groups, which can donate $\mathrm{H}+$ electrons to reactive free radicals hence 


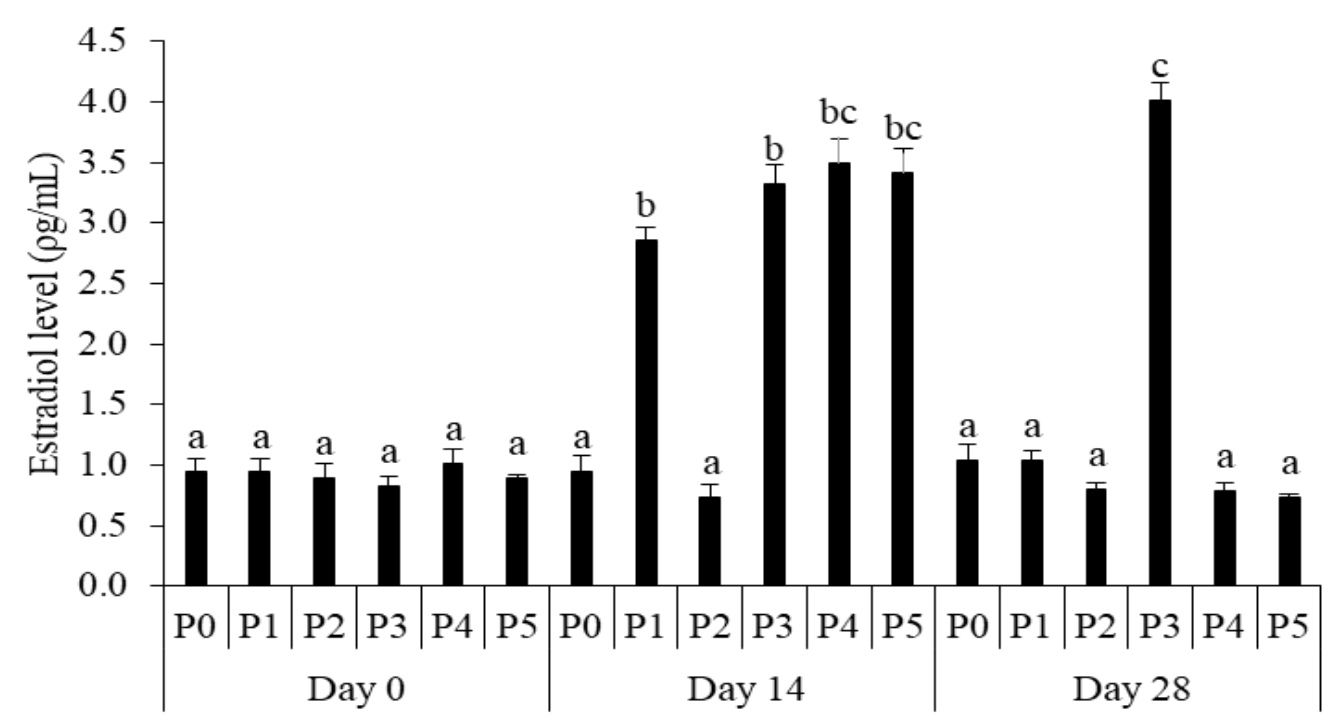

Figure 1. Estradiol level $(\mathrm{gg} / \mathrm{mL})$ of premenopausal white rat blood serum after turmeric powder treatment. P0P5 indicate treatments. Letter indicate significant differences based on the Tukey HSD test $(\alpha=0.05)$. Error bars indicate standard error of the mean of three replicates.

causing them to be more stable [21].

Free radicals are a product of the body's normal metabolism. One of the free radicals is the Reactive Oxygen Species (ROS) group [10]. ROS can cause lipid peroxidation, a chain reaction that will produce MDA, inhibition of the free radical activity of ROS group by curcumin will inhibit also lipid peroxidation process and cause decreasing MDA production [22].

The antioxidant mechanism of curcumin possessing the phenolic group is a hydrogen atom donor. The antioxidant compound (AH) can provide the hydrogen atom rapidly to the lipid radical $(\mathrm{R} \bullet$, $\mathrm{ROO} \bullet$ ) and convert it to a more stable form ( $\mathrm{RH}$ and $\mathrm{ROH}$ ), while the antioxidant radical derivative $(A \bullet)$ has a more stable state compared to lipid radical [11].

$$
\begin{gathered}
\mathrm{R} \bullet+\mathrm{AH} \rightarrow \mathrm{RH}+\mathrm{A} \bullet \\
\mathrm{ROO} \bullet+\mathrm{AH} \rightarrow \mathrm{ROH}+\mathrm{A} \bullet
\end{gathered}
$$

Pure curcumin powder and turmeric powder treatment may increase serum estradiol levels of test animals on the measurement at day 14's estradiol levels, except turmeric rhizome $100 \mathrm{mg} / \mathrm{kg}$ BW (P2) dose which exhibits no improvement compared to control group. Based on estradiol level measurement on day 28, only $200 \mathrm{mg} / \mathrm{kg}$ (P3) dose treatment showed an increase in estradiol levels compared with negative controls (Fig- ure 2).

Increased estradiol levels of white rats blood serum after turmeric powder treatment is suspected due to the phytoestrogen compounds content in the form of phytosterols on turmeric powder $\beta$-sitosterol and stigmasterol [13]. [23] explains that the content of phytoestrogens in turmeric powder ethanol extract can increase rats blood serum estrogen levels. Phytoestrogens likely to directly or indirectly affect elevated rats estrogen level [24], the indirect effect of phytoestrogens on estrogen levels increase is a structural and functional similarity of phytoestrogens with cholesterol, possessing estrogenic function as a natural precursor of the synthesis of steroid hormones such as estrogen [25].

Estrogen is a steroid hormone that has an estrogenic function with many pathways, one of which is affecting the secretion of hormones follicle stimulating hormone (FSH) and luteinizing hormone (LH) through a feedback mechanism [26]. The main natural estrogens in humans are estradiol, estrone, and estriol. Estradiol and estrone are produced by ovarian granulosa and ovarian cells, while estriol degrades estradiol, estrone, and the production of the placenta [27].

The estrogenic potential of phytoestrogens on turmeric powder was suggested can increases estrogen levels in the blood [28]. The content of turmeric powder is similar to cholesterol structure. It 
serves as a precursor to the synthesis of steroid hormones such as estrogen [25].

Phytoestrogens may possess direct effect on increased blood estrogen levels by a direct action of phytoestrogens in ovarian granulosa cells [24]. Direct action of phytoestrogens in estrogen levels increase, for example by the addition of phytoestrogens from outside the body (exogenous estrogens) will work by blocking the production of Gonadotropin Releasing Hormone (GnRH) from the hypothalamus which will impact on the reduced production of FSH and LH hormones from the pituitary, the ovarian follicle develops a minimum and does not ovulate, this condition will retain follicular granulosa cells to continue producing estrogen [23].

\section{Conclusion}

The treatment of turmeric powder administered orally can significantly decrease mature ovarian MDA levels. Treatment of turmeric powder at a dose of $200 \mathrm{mg} / \mathrm{kg}$ BW may increase the blood estradiol levels of white rats on days 14 and 28.

\section{Acknowledgment}

This paper is part of the dissertation of the first author sponsored by BPPDN scholarship, provided by the Directorate General of Higher Education, Ministry of Research, Technology and Higher Education of Republic Indonesia.

\section{References}

1. Gougeon, A. (2003) Dynamics for human growth: morphologic, dynamic, and functional aspects. In: Leung PCK, Adashi EY, eds. The Ovary: $2^{\text {nd }}$ Edition. San Diego, Elsevier. Pp $25-43$. doi: 10.1016/B978-012444562-8/50003-3.

2. te Velde ER, Pearson PL (2002) The variability of female reproductive ageing. Human Reproduction Update 8 (2): 141 - 154. doi: 10.1093/humupd/8.2.141.

3. Gougeon A, Ecochard R, and Thalabard JC (1994) Age-related changes of the population of human ovarian follicles: Increase in the disappearance rate of non-growing and early-growing follicles in aging women. Biology of Reproduction 50 (3): 653 663. doi: 10.1095/biolreprod50.3.653.

4. Cruz G, Fernandois D, Paredes AH (2016) Ovarian function and repoductive senescence in the rats: Role of ovarian sympathetic innervation. Reproduction Advance Publication 153 (2): R59 R68. doi: 10.1530/REP-16-0117.

5. Shen LR, Xiao F, Yuang P et al. (2012) Curcumin-supplemented diets increase superoxide dismutase activity and mean lifespan in Drosophila. AGE 35 (4): 1133 - 1142. doi: 10.1007/s11357-012-9438-2.

6. Zhang DD (2006) Mechanistic studies of the nrf2-keap1 signaling pathway. Drug Metabolism Reviews 38 (4): 769 - 789. doi: 10.1080/03602530600971974.

7. Gonzalez-Reyes S, Guzman-Beltran S, Medina-Campos ON, Pedraza-Chaverri J (2013) Curcumin pretreatment induces nrf2 and an antioxidant response and prevents hemin-induced toxicity in primary cultures of cerebellar granule neurons of rats. Oxidative Medicine and Cellular Longevity 2013: 1 - 14. doi: 10.1155/2013/801418.

8. Valko M, D Leibfritz, J Moncol et al. (2007) Free radicals and antioxidants in normal physiological functions and human disease. The International Journal of Biochemistry \& Cell Biology 39 (1): 44 - 84. doi: 10.1016/j.biocel.2006.07.001.

9. Favier AE, Cadet J, Kalyanaraman B et al. (1995). Analysis of free radicals in biologycal systems. Basel, Birkhäuser Basel.

10. Halliwell B, Gutteridge JMC (2015) Free radical in biology medicine $5^{\text {th }}$ edition (preview). Oxford, Oxford University Press.

11. Schulz O (2008). The Biological activity of curcumin. Wellness foods Europe: 10 - 13 .

12. Li S, Yuan W, Deng G et al. (2011) Chemical composition and product quality control of turmeric (Curcuma longa L.), Pharmaceutical Crops 2: 28 - 54 doi: 10.2174/2210290601102010028.

13. Kusmana D, Lestari R, Setiorini et al. (2007) Efek estrogenik ekstrak etanol 70\% kunyit (Curcuma domestica VAL.) terhadap mencit (Mus musculus L.) betina yang diovariektomi. Makara Journal of Science 11 (2): 90 - 97. doi: 10.7454/mss.v11i2.285.

14. Jurenka JS (2009) Anti-inflamatory properties of curcumin, a major constituent of Curcuma longa: A Review of preclinical and clinical research. Alternative Medicine Review 14 (2): 141 -153 .

15. Somchit MN, Zuraini A, Bustamam AA et al. (2005) Protective activity of turmeric (Curcuma longa) in paracetamol inducedhepatotoxicity in rat. International Journal of Pharmacology 1 (3): 252 - 256. doi: 10.3923/ijp.2005.252.256.

16. Schemedes AV, Helmer G (1989) A new thiobarbituric acid (TBA) method for determining free malondialdehyde (MDA) and hydroperoxydes selectively as a measure of lipid peroxidation. Journal of the American Oil Chemists' Society 66 (6). doi: 10.1007/BF02653674

17. Crowther JR (2001) The ELISA guidebook. Totowa, Humana Press.

18. Darwadi RP, Aulanni’am, Mahdi C (2013) Pengaruh terapi kurkumin terhadap kadar malondialdehid (MDA) hasil isolasi parotis dan profil protein tikus putih yang terpapar lipopolisakarida (LPS). Kimia Student Journal 1 (1): 133 - 139.

19. Kohli K, Ali J, Antasari MJ, Raheman Z (2005) A natural antiinflammatory agent. Indian Journal of Pharamacology 37 (3): 
141-143.

20. Barzegar AM, Movahedi AA (2011) Intracellular ROS protection. Efficiency and free radical-scavenging activitity of curcumin. Plos ONE 6 (10): e26012. doi: 10.1371/journal.pone.0026012

21. Menon VP, Sudheer AR (2007) Antioxydant and antiinflammatory properties of curcumin. In: Anggarwal BB, Surh YJ, Shishodia S eds. The Molecular targets and therapeutic uses of Curcumin in health and disease. Advances in Experimenta Medicine and Biology 595: 105 - 125. doi: 10.1007/978-0-38746401-5_3.

22. Thakur S, Bawara B, Dubey A et al. (2009) Effect of Carum carvi and Curcuma longa on hormonal and reproductive para- meter of female rats. International Journal of Phytomedicine 1 (2009): 31 - 38. doi: 10.5138/ijpm.2009.0975.0185.05791.

23. Zhao E, Mu Q (2011) Phytoestrogen biological action on mammalian reproductive system and cancer growth. Scientia Pharmaceutica 79 (1): 1 - 20. doi: 10.3797/scipharm.1007-15.

24. Amstrong DG (1984) Ovarian aromatase activity in the domestic fowl (Gallus domesticus). Journal of Endocrinology 100 (1): 81 - 86. doi: 10.1677/joe.0.1000081.

25. Turner CD, Bagnara JT (1988) Endokrinologi umum. Edisi keenam. Surabaya, Airlangga University Press.

26. Maligalig, M. D., A. L. D. Lannu, \& B. M. Lontoc. (1994). Estrogenic activity of the aqueous extract of Curcuma longa Linn. Philippine Journal of Science 123 (2): 105 - 109. 